\title{
CHANGE AND PERSISTENCE
} IN «MIGRATING RELIGIONS»

Michel Olga Vaceslavovna, $P h D$ in Sociology

Heilbronn University, 39 Max-Planck-Str., Heilbronn, 74081, Germany

E-mail: omichel@stud.hs-heilbronn.de

\section{A bstrakt}

$\mathrm{T}$ This study explores the preconditions for the change and persistence of religious identity and religious practices in strongly religious transnational messianic movements against the background of their migration experiences. It presents an exploratory comparative micro-analysis of two research cases, i.e., two strongly religious communities, which are located in Germany and which keep different kinds of ties to their superordinate transnational structures. This study raises the question of why in one case a change in religious identity formation takes place, and why this change is absent in the other case. Based on empirical evidence, this article identifies and discusses different religious identification aspects as well as different motivational, organizational and contextual factors responsible for the change or persistence of strongly religious practices and identity formation, against the background of migration.

$\mathrm{K}$

Leywords: religion; migration; change; identity; organization; social movement.

Михель О.B.

ИЗМЕНЕНИЕ И ПОСТОЯНСТВО В «МИГРИРУЮЩИХ РЕЛИГИЯХ»

Михель Ольга Вячеславовна, кандидат социолодических наук

Гейльброннский университет, ул. Макса Планка, д. 39, г. Гейльбронн, 74081, Германия Электронный адрес: omichel@stud.hs-heilbronn.de

\section{АнНотация}

Д

анное исследование рассматривает условия изменения и постоянства религиозной идентичности и религиозных практик в строго религиозных транснациональных миссионирующих движениях с учетом их миграционного опыта. В статье представлен эксплоративный сравнительный микро-анализ двух кейсов, то есть двух религиозных общин, которые находятся в одном и том же городе в Германии и по-разному строят свои отношения с вышестоящими транснациональными структурами. Рассматриваются причины изменения в формации религиозной идентичности в одном кейсе и причины их отсутствия во втором кейсе. Основываясь на анализе эмпирических данных, это исследование идентифицирует и обсуждает идентификационные, мотивационные, организационные и контекстуальные факторы, которые несут ответственность за изменения и постоянство строго религиозной идентичности и практик в религиозных движениях данного типа с учетом опыта их миграции.

Ключевые слова: религия; миграция; изменение; идентичность; организация; социальное движение. 


\section{Introduction}

Scholarly literature identifies several factors that can initiate or support changes in religious identity formation and religious practices against the background of migration processes.

On the one hand, there is the argument that migration experiences can facilitate the transformation of religious identity in the process of acculturation in the receiving society. For example, Baumann (2000) identifies four different transformation processes, stressing the possibility of changes in religious practices as well. The trajectories he describes include the loss, the reinforcement, the preservation or the change of religious traditions $[\mathbf{1}, \mathrm{p} .17]$.

On the other hand, certain researchers have emphasized the role played by religious ideologies and religious organizations, which can guide immigrants through the acculturation process in receiving societies. For example, Yang and Ebaugh (2001) show in their analysis of immigrant religious communities in the United States that religious organizations can expand their functions and change their organizational, ritual and theological foundations in order to support the adaptation of their members to a particular cultural and economic context [2]. Levitt, too, (2002) argues in her exploration of the institutional characteristics of transnational religious organizations that the latter also influence the integration of religious immigrants in receiving societies [3]. She [Levitt] identifies three types of transnational religious organizations: (a) Extended religious transnational organizationsintegrate their migrant adherents into "powerful, well-established networks where they can express interests and make claims with respect to their home and host countries" [3, p. 3-4]; (b) negotiated religious transnational organizations involve their migrant followers in an «emerging set of cross-border organizational arrangements» that encourage an inner-worldly or other-worldly «working for God» [3, ibid.], including church-related activities or other forms of social and political engagement in a receiving society; and, (c) finally, recreated transnational religious organizations strongly reinforce members' "ties to their home country, often at the expense of furthering receiving-country social integration" [3, ibid.].

Matras (1964) offers additional insights into changes in religious identity formation and reli- gious practices: He [Matras] detects intergenerational change as a possible and important factor in this context [4]. However, the transformation processes induced by intergenerational change may also depend on contextual circumstances, denominational aspects, and experiences of discrimination in the receiving society $[5,6,7]$.

Furthermore, it is pivotal to consider the organizational goals of transnational religious organizations concerning their (a) migration incentives and (b) positioning to the organizational environment. The research conducted on migration and transnational religious movements shows that collective religious actors have varying incentives to involve themselves in international migration flows. For example, Martin Baumann (2000) differentiates between migration for the purpose of religious missions in «the world" and migration for other purposes, including different push and pull factors [1, p. 15]. This means that migration incentives can have a different impact on acculturation processes in a receiving society and can differently correlate with the transformation of religious practices and religious group identity. In addition, the research on strongly religious movements shows that the organizational goals of collective fundamentalist religious actors are very important for their positioning to the particular organizational environment. This positioning is ideologically-based and shaped by rejection of "the sinful world" outside their organizations. Almond, Appleby, and Sivan (2003) distinguish four main patterns to relate to the organizational environment in the field of strongly religious movements: These are world-renouncement, world-conquering, world-transformation and world-creation [8]. It is conceivable that the mode of strongly religious relating to «the world « may influence how strongly religious migrants might interact with their environment, how they experience acculturation processes and whether or not they go on to transform their strongly religious identity in particular cultural contexts of the receiving societies.

Last but not least, there are several studies which show that the contextual factors and thematic discourses on religion and migration in the receiving society can play an important role in fostering or impeding cultural convergence (German: kulturelle Annäherung) between a 
receiving society and strongly religious groups with migration experiences $[1,6]$.

Research objective: Drawing on these theoretical considerations, this study combines the aforementioned discourses concerning (a) transnational religious movements (TRM) and their motivations for migration, (b) strongly religious movements with different modes of world-denying, and (c) transformation of religious identity and practices. Special attention goes to different factors which can lead to a change of religious identity and religious practices, including self-identification codes, ideologically-based relationships with a particular organizational environment, migration incentives, types of migration, and the cultural context of the receiving societies. The following graph 1 visualizes the research objective of this study:
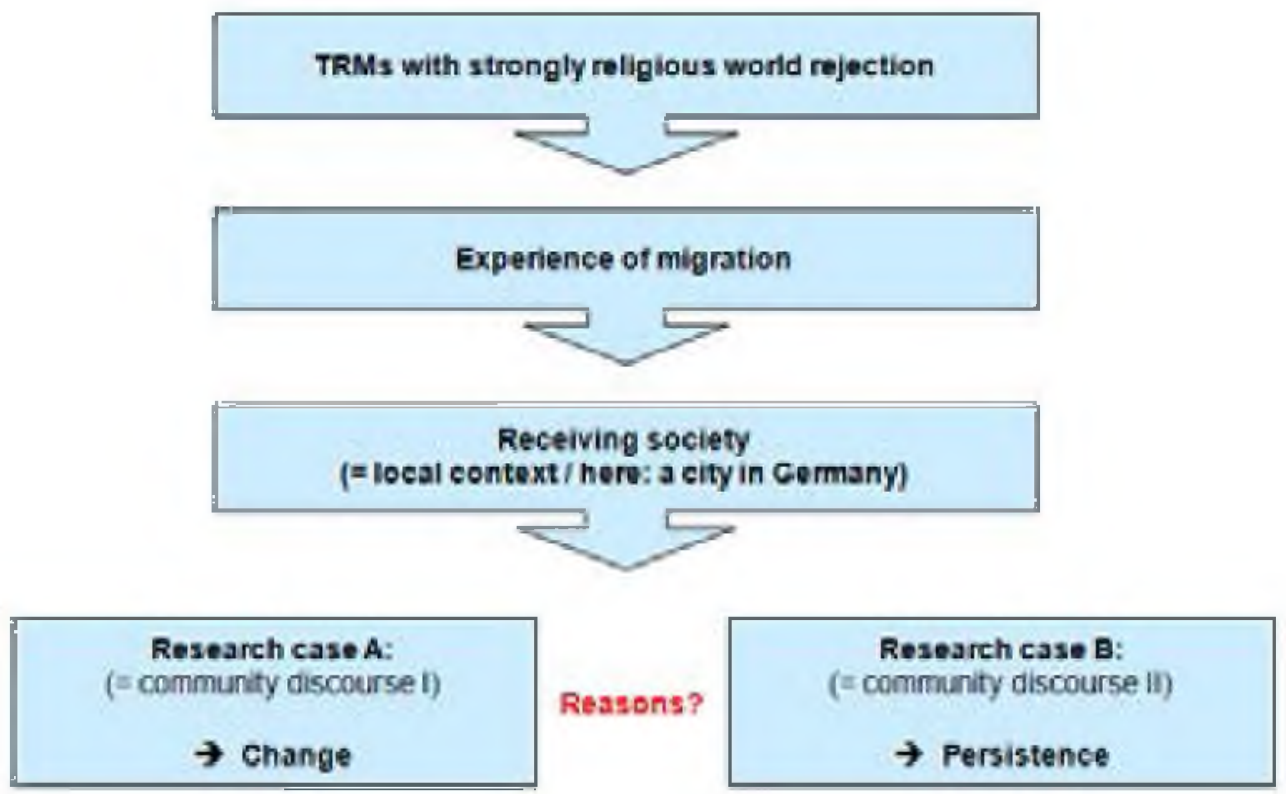

Graph 1. Research objective

\section{Methodology}

Research focus and research questions: This study aims to explore possible factors and conditions which lead to the transformation of the religious identity formation and religious practices or which induce institutional persistence of the latter. The analysis focuses on the community level of «migrating religions» (i.e., strongly religious messianic transnational movements). Accordingly, the main research questions of this study are as follows:

1. When do communities of strongly religious transnational movements tend to change their religious identity formation against the background of their migration experiences and encounters with culturally different contexts of the receiving society? When, on the contrary, do they tend to preserve their religious identity?

2. Which factors can influence the change or persistence of religious identity and practices?

Empirical basis, sampling and methods of analysis: This study is based on different sources of data (i.e., ethnographic data, interviews and the analysis of available documents) from my research, conducted in Germany from 2008 to 2011 in the framework of a larger project on religious world-denying, conflicts and processes of social differentiation $[9,10]$. By means of selective sampling, I chose two communities of transnational religious movements which were located in the same city and which differently framed the possibility of transformation of their group identity in the culturally different context of their current country of residence (i.e., Germany - see more below). Following Strauss (1998), I use the Grounded Theory methodology to generate empirically-based, conceptually-thick descriptions of the processes which supported or induced transformation of the religious group identity in one case and prevented this transformation in the other case [11]. Keeping in mind my research interest and considering the possibility of different factors impeding or fostering the transformation of a strongly religious identity formation, I apply a multiple case inquiry as a research strategy. Following 
Yin (2009), I differentiate between two levels of analysis in this framework: These are within-case analysis (reconstructing a research case as such) and cross-case analysis (juxtaposing the results of the within-case reconstructions) [12]. Accordingly, this study reconstructs selected research cases in a separate section for each within-case analysis, followed by the comparison of these results in the framework of a cross-case synthesis.

Research cases: (1) The first research case involves a community of Mennonites from the former Soviet Union. This community began a partial transformation of its religious group identity and certain religious practices several decades ago. (2) The second research case involves a community of the Brighamite branch of Mormonism, in which no transformation process of group identity or religious practices could be observed in the last decade. These research cases offer the following common characteristics: (a) Both communities belong to larger transnational religious movements, i.e., "migrating religions»; (b) the organizations' members have previous migration experience (as missionaries or otherwise) and reside in the same social setting, in a large city in Western Germany; and (c) both communities can be characterized as «strong religions» [8] (that is, they have an exclusionary code of their religious group membership, the claim of salvation only for own organizational members, missionary practices, and the reference to world-denying in their organizational ideologies). At the same time, these research cases differ in the following features: (a) manifestation of the transformation processes relative to religious group identities and practices on the community level; (b) migration incentives; (c) relationship towards the organizational environment, and (d) organizational structure.

For example, the first research case (i.e., a community of Mennonites from the former Soviet Union) manifests several transformation processes relative to the constitution of religious group identity and certain religious practices in the course of acculturation in the receiving society. These changes concern their mode of religious world-rejecting, organizational ideology and certain religious practices. Female community members, for instance, are now allowed to wear trousers at community meetings during the week (i.e., from Monday to Saturday), as well as knee-length skirts and earrings during the Sacrament meetings on Sunday. And along with these changes in their religious practices, rhetoric of apocalyptic expectations and religious world-denying was lessened in organizational discourse, at least on the level of leadership and among the second and third generations of community members. Both their exclusionary religious orientation and the relevance of the bookish tradition do still remain central to the constitution of the group's identity. However, the community does not exclude itself from «the world», i.e., the organizational outside. On the contrary, it endeavors to transform the organizational outside (i.e., "the world») wherever possible, according to its definition of Christian values. Considering the classification of strongly religious movements [8], one can observe in this case the transformation from the mode of world-renouncers to the mode of world-creators in this research case on the level of community discourse. This community not only cooperates with other communities of Mennonites with the same experience of migration from the former Soviet Union, it is also connected to autochthonous free evangelical unions and churches, participating in missionary activities abroad (e.g. in Africa, Israel and other foreign countries) as well as promoting evangelization and their religious values amongst youth in Germany. In order to attract the autochthonous population to their community, they name themselves not as the "Mennonite Community", but the "Community of Christ» (German: Christusgemeinde).

In the other research case, contrarily, no such transformative development was observable. This difference is the starting point for a sociological analysis. In the following I will present a reconstruction of these two research cases, identifying reasons for the transformation of identity formation and religious practices in the first research case, and discussing reasons for their absence in the other research case.

\section{Within-Case Reconstruction I: Trans- formation of Religious Identity}

In the first research case (i.e., a community of Mennonites from the former Soviet Union) the community members derive their understanding of migration processes and organizational goals pertaining to migration simultane- 
ously from two codes of self-identification - that is, from their ethnic and theological self-determination as Christians in the world, and as ethnic Germans. Theologically, as «the people of God», community members are «on their way to heaven»; and historically, they are the ancestors of ethnic Germans, who immigrated to Tsarist Russia during the reign of Catherine the Great and returned to their historical homeland in the last century.

This intersection of religious and ethnic codes in identity formation provides the basis for a means-end-calculation relative to their relationship to the organizational environment, and to their migration incentives, migration experiences and adjustment processes in their current country of residence (that is, in Germany). These community members define their migration as «returning to their historical homeland». The type of migration to Germany in this research case can be defined as both return migration and chain migration. However, this incentive to migrate is interwoven with their religious code as well: As «the people of God", community members adjust their personal lives and their living space to be in line with their understanding of 'divine laws' and religious traditions. If living according to their religious creed in a society is not possible and there is a possibility of migration, then the faithful migrate to another place, where the freedom of belief is provided and where they can enjoy more freedom while practicing their religion. This religious self-distinctness shapes the migration and adjustment process in this research case, too. The idea of migrating back home for the purpose of ethnic reunion after a centuries-long history of migration and multiple selfand other-induced estrangements in foreign countries instills in many community members a strong sense of ethnicity as Germans and a strong longing for their homeland. This ethnic self-determination provides significant motivation for acculturation in Germany as the receiving country and historical homeland, to the extent that it does not collide with their religious self-distinctness.

In addition, this ethnic self-determination provides the basis for connectivity and matching in the framework of the ethno-national state of Germany. On the one hand, the strongly religious orientation did not gain much recognition, especially among the non-religious autochthonous population; and, certain identity markers and cultural differences of first-generation migrants (such as special hairstyles, specific dress codes, an Eastern European accent, etc.) led to identity and recognition conflicts (German: Identitätsund Anerkenmungskonflikte) in their historical homeland. On the other hand,the German state supported the structural and economic integration of this group of immigrants with additional support (e.g., language courses, non-interest bearing loans, etc.). Furthermore, some autochthonous evangelical groups also encouraged religious and cultural exchange with Mennonite migrants from the former Soviet Union. In this way, this particular research case developed cultural convergence which was supported by the match of ethnic and religious codes in the self-determination of this particular migrant group and certain religious movements in the receiving society. However, the way to the currently observable cooperation with autochthonous evangelical groups has taken several decades, and such religious and cultural convergence cannot be found in any case of Mennonite communities living in Germany. We should also keep in mind the contextual factor at work here: Living in a large city, the community being studied could easily make use of the religious diversity in the given social space, which could be more difficult in a remote village with a less varied religious landscape.

Along with the common ethnic code connecting this migrant group to the receiving society, and along with the specific ethno-religious self-determination shaping their motivation to migrate, and positioning in relation to the organizational environment; the transformation of religious group identity and religious practices was supported in this case by several additional characteristics of the organizational discourse under analysis:

(1) First and foremost, there is a certain organizational independence of the so-called «base-communities» (German: Basisgemeinde) of Mennonite churches of each other. This institutional independence allows for variations in their organizational discourses and ideologies, including the issues of migration and acculturation processes in the receiving society. Since such «base-communities» are part of a negotiated transnational religious network [cf. 3] free of specific hierarchies, decisions concerning the reproduction of any particular organizational discourse and relations with 
the organizational environment can be made according to particular community resources as well as contextual and situational opportunities and circumstances. Although centrality of a strongly religious orientation remains the central characteristic of this «base-community», specific adjustments to the organizational environment can be made over time, according to the orientation of community members as well as the receiving society with its particular population groups (i.e., evangelical free churches).

(2) Another important issue, which enhances the speed of organizational development and which in this research case also contributes to certain transformational processes, is relative to the rapid intergenerational succession in the leading positions (e.g. such as lay preachers). This rapid succession in the organizational structure and additional orientation of the community's management of the good relations and cooperation between members (German: beziehungsfokussiertes Miteinander) make organizational hierarchies more permeable and prevent gerontology. Although the leadership of this community is exclusively male, the position of lay preachers and the focus on good relations in the community development enable this community to integrate the voices of different generations in the construction of organizational discourse. This fosters intergenerational exchange and the simultaneous participation of the first, second and third generations of migrant Mennonites on the organizational level. The orientation of the group's leadership (the council of Elders) on good relations and cooperation is part of the organizational culture, and provides an opportunity for productive intergenerational exchange in the organizational structure. For the community under study here, these conditions create further chances for the transformation of the particular mode of religious world-rejecting from world-renouncement to world-creating. They also induce the change of several religious practices.

(3) Finally, the mechanisms of organizational closure have to be mentioned in the following context: For this community, the myths of organizational descent (German: Ursprungsmythos) shape the narrations pertaining to self-determination and contain storylines about their history of religious and ethnic persecution, scattering, displacement, and migration firstly during the
Protestant Reformation in Europe, and subsequently during the Second World War, as well as in the post-war era in the former Soviet Union and in Germany. These storylines are preserved in the collective memory of this community and frame the symbolic and organizational boundaries between this strongly religious collectivity and its organizational environment. For example, the reminiscence of ethnic tensions roots in the remembered history of displacement and discrimination in the former Soviet Union. This reminiscence fills the communicative memory of the first and second generations of community members; and, in situations of identity-threat, ethnic competition and conflict, these remembered ethnic tensions can induce self-victimization or take the form of group-based animosity. Religion-based enemy images are another example of storylines, which define symbolic and organizational boundaries of this community: These images appeared during the Protestant Reformation in Europe and relate to the distant past in the structure of the organizational memory culture. These ethnic and religious semantics in the communicative memory of this organization shape particular lines of group boundaries. However, they do not impede communication with the current organizational environment in Germany. Moreover, in situations of recognition conflicts (German: Anerkennungskonflikte) with the autochthonous population or in situations of ethnic competition between different migrant groups, the semantics of group-based animosities even help to gain socially favorable positioning. This specific expression of symbolic and organizational boundaries not only encourages communication with the organizational environment, it also creates further chances for the transformation of religious identity. The rhetoric of strongly religious world-rejecting with generalized hostile attitudes towards «the sinful» and towards the so-called «inconsequent» styles of religiosity remains an integral part of the organizational discourse, and is directed toward the immediate organizational environment. However, this rhetoric does not prevent community members from cooperating with autochthonous religious groups, whose religious self-understanding is close to the organizational ideology of this Mennonite community.

I sum up the results of this within-case reconstruction in the following graph: 


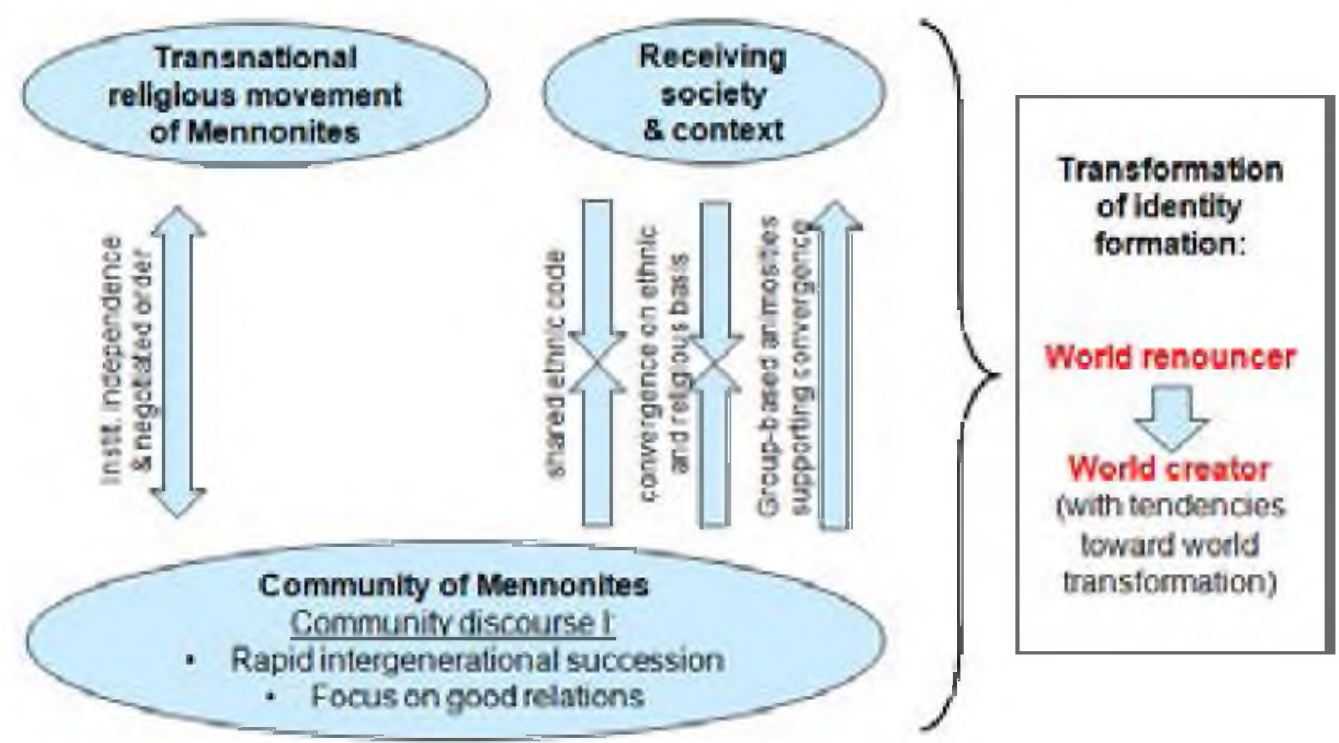

Graph 2. Conditions for the partial transformation of strongly religious identity in the research case I

\section{Within-Case Reconstruction II: Persistence of Religious Identity}

The second research case involves a community of the Brighamite branch of Mormonism. This community is situated in the same city in Western Germany, and is comparable in size to the Mennonite community under study. The Brighamite branch of Mormonism also has a long tradition of transnational migration. Like the first research case, the community under analysis here has to be defined as a strongly religious movement. However, the main feature of its relationship towards the organizational environment is characterized by the mode of world-transforming. Unlike the first research case, no transformation of religious identity or religious practices can be observed in this community. Like in the first research case, the following analysis focuses on the organizational discourse as a whole, on the particular discursive storylines relative to the code of the organizational Self and its role in the definition of migration incentives, as well as on the relationship towards the organizational environment. Both the migration incentives and the relationship of this transnational religious movement with its organizational environment are based in this research case exclusively on religious self-determination. As a church with the world-transforming mode of adjustment to the organizational environment, it integrates in its organizational ideology and discourse the requirement of missionary activities as a part of the group's religious iden- tity. Only by transforming 'the world', - that is, by spreading 'the word of God', recruiting new organizational members and setting up new communities of followers all over the world does a community member have the chance to obtain personal salvation and eternal life in «the Kingdom of God» [10]. The incentives of organizational members to migrate to Germany or to another place of mission are therefore legitimized theologically, at least on the level of organizational discourse. As a result, taking part in a mission, organizational members are involved in a kind of circular migration: Missionaries from the US and the autochthonous members of this community are regularly sent on missions to other German cities or other foreign countries. After their missionary work, the missionaries usually return to their home communities in their countries of origin. The mission implies «working for God», aiming at a step-by-step transformation of the organizational environment in line with organizational values and identity features. The missionaries support organizational growth by setting up new communities and by supporting already established communities in their development. In preparing for their missionary work abroad, the members of this movement are instructed to respect local laws, i.e., national legislations in the places of their mission and to be polite with other people. This guideline frames the process of adjustment in the receiving society (i.e., the target societies of the mission) as well. However, their missionary duty remains 
a priority for its members in any receiving society. Therefore, interaction with non-members is largely influenced by these organizational directives and usually does not lead to personal bonding with representatives of the organizational environment or to the quest for new information about a receiving society. As a consequence, the chances of experiencing a transformation of the religious code on the organizational level are kept to a minimum.

In addition to this theologically legitimized attitude to the migration process and positioning towards the organizational environment; the continuity and stability of organizational discourse (relative to the issues of mission, migration and organizational policy in «the world») are supported by the following aspects, which also hinder its transformation:

(1) Following Levitt $[3$, p. 6], this movement can be identified as an extended religious transnational organization, given that it integrates all of its members in powerful organizational structures with a particular ideological positioning in relation to its organizational environment. Being a part of such organization, the community's discourse is strictly shaped according to the organizational ideology and supervised by several institutions of formal and informal control. The centralized management, strong ties to religious authorities in the U.S., strict hierarchy between different levels of leadership and different organizational positions, and attribution of transcendent qualities to the organization and its structures (i.e., positions, roles, rules etc.) not only ensure the continuity of organizational ideology, but also provide a mechanism for the suppression of any transformation processes at the local level.

(2) The slowness of organizational development and therefore the limited chances of transforming organizational ideology are also determined by the age structure of organizational leaders. Management of the church can be characterized as a gerontocracy, implying very little intergenerational succession in the top management positions of the church.

(3) Finally, the organization's discourse and ideology contain several generalized semantics of animosity and enemy images, which are functionally used in the organizational boundary management. These semantics characterize organizational myths of descent and reconstruction, and the myth (or rather the vision) of the prophesied future with regard to salvation. In all of these myths, the generalized images of external «enemies» are related to the immediate organizational environment. In addition, the organizational discourse is protected by references to images of internal «enemies» (e.g. «deviants» [German: «Abweichler»]), which are designed to preserve the 'purity' of organizational ideology. Such generalized images of internal and external «enemies» prevent the initiation of intra-organizational conflicts and debates concerning the structure of the organizational discourse, thereby preventing any possibility of transformational processes.

I sum up the results of this within-case reconstruction in the following graph:

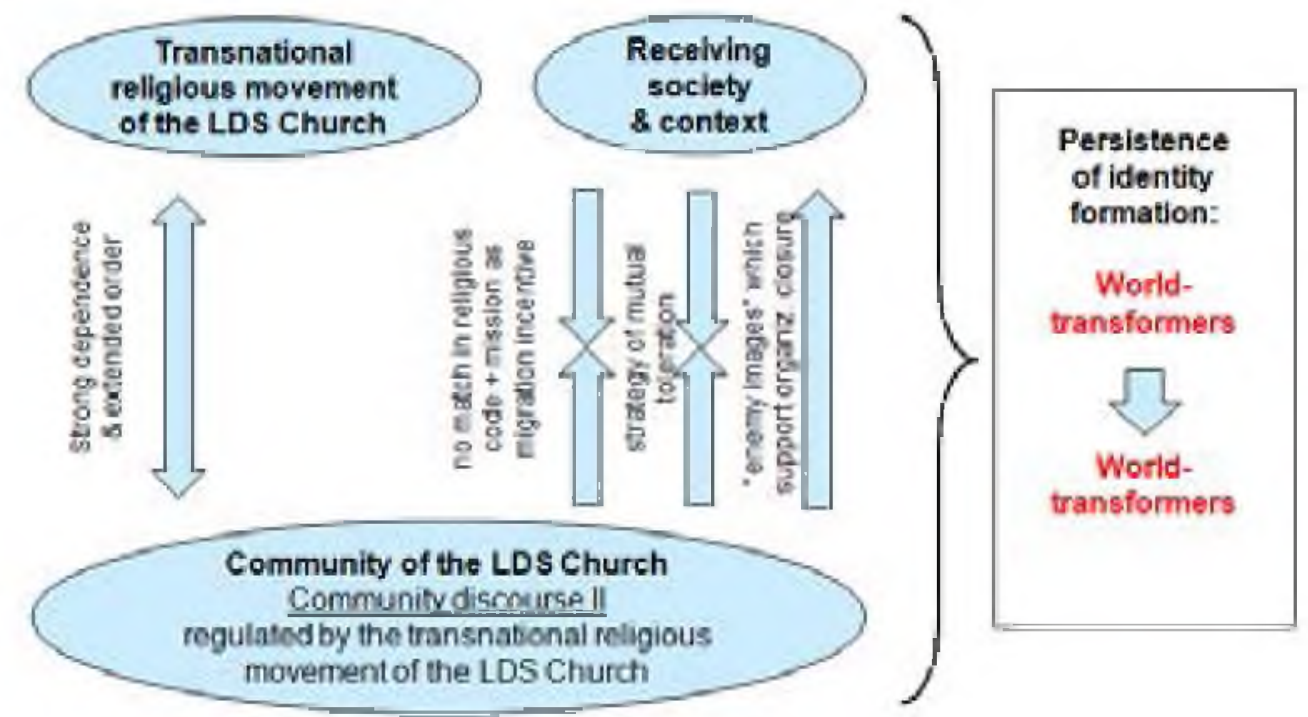

Graph 3. Conditions for the persistence of strongly religious identity in the research case II 


\section{Cross-Case Analysis: Conditions for Transformation and Persistence}

Although both communities under analysis may be characterized by several common features, they respond differently to the possibility of religious identity transformation in the receiving country. Both communities represent larger transnational religious movements, and both define themselves as strong religions, with a typical tendency to deny «the sinful world» (i.e., the organizational environment) and other lifestyles, including other forms of religiosity. Both communities also share the same social context in the receiving society and are located in the same city in Western Germany. However, in the first research case (i.e., in a community of Mennonites from the former Soviet Union) one can observe the transformation of certain religious practices, of organizational ideology and certain aspects of religious identity (insofar as the mode of the religious world-rejecting is concerned); and in the second research case (i.e., in a community of the Brighamite branch of Mormonism), no such transformation process took place, in the period of time under analysis.

The research results in the following table (see Table 1) describe the major characteristics of the analyzed research cases considering their different tendencies to transform or maintain religious identity against the background of migration processes. Following the guidelines of cross-case analysis, I juxtapose central identification aspects as well as motivational, organizational and contextual factors, and define their expressions relative to the transformation or persistence of religious identity, organization and practices:

Factors responsible for the transformation or persistence of religious practices

Table 1 and religious identity in two research cases

\begin{tabular}{|c|c|c|}
\hline \multirow{2}{*}{$\begin{array}{l}\text { Characteristics } \\
\text { of the transnational } \\
\text { relig. organizations }\end{array}$} & $\begin{array}{c}\text { Research case I: } \\
\text { A community of } \\
\text { Mennonites from the } \\
\text { former Soviet Union (in } \\
\text { Germany) }\end{array}$ & $\begin{array}{c}\text { Research case II: } \\
\text { A community of the } \\
\text { Brighamite branch of } \\
\text { Mormonism (in Germany) }\end{array}$ \\
\hline & $\begin{array}{l}\text { Transformation of } \\
\text { religious identity }\end{array}$ & $\begin{array}{c}\text { Persistence of } \\
\text { religious identity }\end{array}$ \\
\hline \multicolumn{3}{|c|}{ Identification aspects and motivational factors } \\
\hline Self-determination via ... & $\begin{array}{l}\text { Intersection of religious } \\
\text { and ethnic codes }\end{array}$ & Religious code only \\
\hline $\begin{array}{l}\text { Prior characteristics of the religious } \\
\text { code and religious positioning towards } \\
\text { the organizational environment («the } \\
\text { world») }\end{array}$ & $\begin{array}{l}\text { Strong religion with } \\
\text { the mode of world- } \\
\text { renouncing, which } \\
\text { changed into the mode of } \\
\text { world-creating }\end{array}$ & $\begin{array}{l}\text { Strong religion with } \\
\text { the mode of world- } \\
\text { transforming }\end{array}$ \\
\hline $\begin{array}{l}\text { Transformation of the religious code } \\
\text { and religious positioning towards the } \\
\text { organizational environment («the } \\
\text { world») }\end{array}$ & $\begin{array}{l}\text { In the last decades the } \\
\text { mode of world-renouncers } \\
\text { was transformed into the } \\
\text { mode of world-creators } \\
\text { with tendencies toward } \\
\text { world-transformation }\end{array}$ & $\begin{array}{l}\text { No transformation } \\
\text { of religious code or } \\
\text { positioning to 'the world' }\end{array}$ \\
\hline Migration to Germany is motivated by & The ethnic code & The religious code \\
\hline
\end{tabular}


Type of migration

Attitude towards migration and acculturation in the receiving society is determined by
Return migration \& chain $\quad$ Circular migration migration

A common ethnic code with the receiving society
The religious code, defined by the motivation of missionary work in «the world»

\section{Contextual aspects}

Contextual framework for migration and acculturation, as well as support in acculturation processes, provided by the receiving society

\section{Organizational aspects}

Type of transnational religious organization (TRO) (a) Additional support in structural integration, based on a common ethnic code.

(b) Support in cultural integration, provided by autochthonous religious communities with a strongly religious orientation (a) General regulations of migration to Germany

(b) Support by the already established community of this movement and its members
The character of intergenerational succession in organizational management

Group-based animosities or «enemy images» in the organizational discourse and in the collective memory of organizations
Part of a negotiated TRO, with a decentralized form of management on the transnational level and relationship-focused community development on the local level

Participation of different generations in the construction of the community's discourse

... root in the remembered and experienced discrimination, scattering, displacement and migration, experienced during the Protestant Reformation, in the former Soviet Union and in Germany
Part of an extended

TRO with centralized management, a strong organizational hierarchy, and diverse mechanisms of formal and informal control

Gerontocracy with limited intergenerational succession in the top management positions

«Enemy images» are generalized and relate to the immediate organizational environment. They also target criticism concerning organizational ideology inside and outside the community 


\section{Concluding Remarks}

The analysis shows that the incentive for migration is a deciding factor in determining whether or not strongly religious communities representing larger transnational religious movements will undergo transformational processes in the context of a culturally different society. However, even if return and chain migration (with an emphasis on the ethnic code in organizational self-determination) are one of the major motivations for migration in the first research case, it is not the only factor which supported transformation of certain religious practices in the community of Mennonites under study. The analysis identified the following additional factors: (a) the matching code in self-determination (in this case, the ethnic code) of the migrant Mennonites from the former Soviet Union and their receiving society, (b) mutual interest in a partial incorporation and (c) the specific structure of organizational and societal discourses which foster exchange, communication and cooperation between this group and autochthonous religious actors. Even if partial transformation took place in this research case, though, we should treat this result cautiously, given that the cultural convergence of this group of migrants proceeded on the basis of an ethno-religious code: That means that these were the ethno-religious autochthonous groups who (among other factors) could support the transformation of the strongly religious code of migrant Mennonites from strongly religious world-renouncing to world-creating (with tendencies toward world-transforming).

This study identifies the following factors as being important to consider in the exploration of change and persistence in strongly religious transnational movements and their local repre- sentatives: These are (a) organizational regulations pertaining to the change in particular organizational discourses, (b) goals-and-means-relations in the relationship with the organizational environment, which has roots in the mode of religiously-motivated world-denying, (c) patterns of interpretation concerning migration purposes and adjustment on the local level, (d) alternation of generations, (e) collective memory concerning the myths of descent and reconstruction, as well as the plan of salvation, and (f) self-victimization in myths of organizational development, as well as possible intergroup tensions which can lead to rhetoric of animosity and which can legitimize "enemy images" in organizational ideologies. Summing up, several factors were involved in fostering the transformation of religious group identity and certain religious practices in one case, while preventing this transformation in the other research case.

A final comment relates to the framework of the possible generalization and application of the research results from these empirical case reconstructions. Following Max Weber's ideal type methodology, the results of this study can be interpreted and applied only as patterns of processes, which might be found under certain circumstances according to the makeup of diverse and complex social realities [13, p. 332]. The identified ideal type patterns are not the only possible way of transforming or preserving practices in strongly religious communities that can emerge in real-life contexts. That is why the transferability of these research results from this micro-analysis to other possible empirical cases should proceed according to the case-to-casetransfer method [13, p. 319]. 


\section{REFERENCES:}

1. Baumann M. Migration - Religion - Integration. Buddhistische Vietnamesen und hinduistische Tamilen in Deutschland. Marburg: Dialog - Verlag, 2000. $240 \mathrm{p}$.

2. Yang F., Ebaugh H.R. Transformations in New Immgrant Religions and Their Global Implications // American Sociological Review. 2001. Vol. 66. № 2. Pp. 269-288.

3. Levitt P. Redefining the Boundaries of Belonging: Thoughts on Transnational Religious and Political Life // The Center for Comparative Immigration Studies - Working Paper 48. March 2002. San Diego: University of California. 60 p. URL: http://ccis.ucsd. edu/wp-content/uploads/2012/o8/wrkg48. pdf (date of access: September 3, 2015).

4. Matras J. Religious Observance and Family Formation in Israel: Some Intergenerational Changes // American Journal of Sociology. 1964. Vol. 69. № 5. Pp. 464-475.

5. Fleishmann F., Phalet K. Integration and Religiosity among the Turkish Second Generation in Europe. A Comparative Analysis across Four Capital Cities // Ethnic and Racial Studies. 2012 (Vorab online publiziert 11. Juli 2011). Vol. 35. № 2. Pp. 320-341.

6. Fleischmann F., Phalet K., Klein O. Religious Identification and Politicization in the Face of Discrimination. Support for Political Islam and Political Action among the Turkish and Morocean Second Generation in Europe // British Journal of Social Psychology. 2011. Vol. 50. № 4. Pp. 628-648.
7. Hirschman Ch. The Role of Religion in the Origins and Adaptation of Immigrant Groups in the United States // International Migration Review. 2004. Vol. 38. № 3. Pp. 1206-1233.

8. Almond G.A., Appleby S.R., Sivan E. Strong Religion. The Rise of Fundamentalisms Around the World. Chicago et al.: University of Chicago Press, 2003. 281 p.

9. Michel O. Spheres and Trajectories of Religiously-Motivated Activism in the Field of Strongly Religious Movements // Partecipazione e Conflitto. 2014. № 7(1). Pp. 83-110.

10. Michel O. Religiöse Weltablehnung und Positionierung zum «abweichenden Anderen». Theorie der positionalen Konfliktperformanz am Beispiel des streng religiösen Feldes. Dissertation an der Leibniz Universität Hannover. Hannover: TIBUB, 2014. 388 p. URL: http://edoko1.tib.uni-hannover.de/edoks/ e01dh14/810902885.pdf (date of access: October 3,2015 ).

11. Strauss A. Grundlagen qualitativer Sozialforschung. Datenanalyse und Theoriebildung in der empirischen soziologischen Forschung. München: Fink, 1998. 372 p.

12. Yin R.K. Applications of Case Study Research. Los Angeles et al.: Sage, 2012. 231 p.

13. Przyborski A., Wohlrab-Sahr M. Qualitative Sozialforschung: ein Arbeitsbuch. München: Oldenbourg Wissenschaftsverlag, 2008. $403 \mathrm{p}$. 